\author{
Vasyl Kyfyak \\ Chernivtsi Institute of Trade and Economics \\ of Kyiv National University of Trade and Economics \\ tourbuc@ukr.net \\ Olexander Kyfyak \\ Yuriy Fedkovych Chernivtsi National University \\ alkyfyak@bigmir.net
}

\title{
A METHODOLOGY FOR CALCULATING INDIVIDUAL INDICATORS OF TOURISM ACTIVITY
}

\begin{abstract}
The purpose of the article is to find modern approaches for calculating the quantity of given characteristic features and accompanying tourist services and goods purchased by tourists, to determine the number of tourists visiting a city and forecasting the volume of travel services for the future. Solutions to the tasks set out in the article have been carried out with the help of both general academic and specialist research methods: analysis and synthesis, systematization and generalization, expert evaluation and extrapolation. Using the example of the city of Chernivtsi (Ukraine) the number of tourists visiting the city has been determined, the volume of services rendered and the average annual growth rate of tourism service implementation over the last five years has been calculated contributing to forecasting the volume of service delivery for the future.
\end{abstract}

Keywords: leisure, tourism space, recreational space.

\section{INTRODUCTION}

The development of tourism as an industry is characterized by a large number of indicators that show tourist resources, financial and economic activities and their effectiveness, its impact on the development of cities, regional and national economies, and indicators of tourism market monitoring, etc.

Using the example of Ukraine and, in particular, the city of Chernivtsi, it is proposed to calculate individual indicators that reflect the volume of tourism services, the number of tourists, the availability of tourism resources and the impact of tourism on social-economic development. This is to determine the average annual growth rate of the sales of tourism services and to predict sales volumes for future periods.

\section{DETERMINING THE ISSUE}

Ukraine with its unique recreational and tourist resources has enormous potential for the development of foreign and domestic tourism. "The total area suitable for tourism and recreation in natural landscapes is
9.4 million hectares, which is still not fully developed. There are more than 125000 archeological, architectural, urban, historical and artistic monuments and hundreds of museums" (KYFYAK 1995).

In spite of conflicts in the eastern part of the country and other economic and social problems, Ukraine is a leader in terms of attracting foreign tourists. According to the press-office of the Administration of the State Border Guard Service of Ukraine, it is in the top 10 in terms of numbers crossing its borders in 2017, the number of visitors increasing to almost 13 million. ${ }^{1}$ According to expert opinion, Ukrainian tourism can fill state and local budgets annually by tens of billions of hryvnias, generating up to $10 \%$ of annual budget revenues, without taking into account the multiplier effect on related fields.

At the same time, according to statistics, there is a decrease in the volume of sales of tourism services, which contradicts the increase in incoming tourists and the development of tourism infrastructure. This indicates a lack of consideration for tourist expenditure and the provision of many tourist services in the shadow sector. 
The need for the development and implementation of modern methods for calculating the volume of tourist services provided and goods purchased by tourists over a limited period of time, the number of tourists determines the relevance of academic research that will help to establish the real impact of tourism on the economic development of a region or city, determining the economic and social importance of tourism among other sectors of the economy and the development of a corresponding strategy.

\section{ANALYSIS OF RECENT RESEARCH}

The academic works of many foreign and local researchers are devoted to issues of the territorial organization of tourism activity and determining its impact on the development of a region or city, the development of new routes and the organization of tourists' accounts, statistical observations and the use of methods for calculating the volume of tourist services consumed. In particular, Polish researchers A. Stasiak, J. Śledzinska and B. Włodarczyk in their work Szlaki turystyczne. Od pomystu do realizacji [Tourist routes: from plan to implementation] (STASIAK, ŚLEDZINSKA \& WŁODARCZYK 2014), determine the importance of developing new tourist routes and their importance in the formation of tourist flows. S. Liszewski in his work Miasto i turystyka [The City and Tourism], based on the example of the city of Lodz (Poland), outlines the main causal relationships between the functions of the city and the structure of tourism, which has a significant impact on the city's social-economic development (LISZEWSKI 2017). In the monograph Turisticheski pazari [Tourist markets] Bulgarian specialists S. Rakadzhieska and S. Marinov present their view of the main qualitative characteristics of the tourist market and include a determination of quantitative indicators (RAKADZHIESKA \& MARINOV 2005). In order to analyze regional tourism development data and to calculate the volume of services provided for tourists as well as the number of tourists, a shift-share analysis is used. It is described in the study "Analysis of the dynamics of the tourism industry in Brazil: challenges and recommendations" by Filipe Sobral from Portugal, and Alketa Peci and Gustavo Souza from Brazil (SOBRAL, PECI \& Souza 2007). This method, based on the example of measuring and analyzing the growth in numbers of tourists coming to South America not only allowed this to be determined, but also explained their behavior and to more profoundly diagnose the dynamics of the tourism sector in a particular period. Ukrainian academics Kravtsiv, Evdokimenko, Gudz, Tsybukh, Milashko, Herasymenko and Pavlots'ky and others believe that the tourism sector has a significant impact on the development of the general and special infra-structure of a region, is an essential source of foreign exchange earnings and contributes to the development of related activities. Thus, in particular, Tsybukh claims that the provision of tourist services and the acquisition of related products actively supports the operation and development of a large number of enterprises in a region. More than 40 spheres of economics are found in the tourist sector: from the agro-industrial complex - to feed the guests, to law enforcement agencies - to ensure order and security (TSYBUKH 2004). But the counting of tourists and the volume of services provided for them is carried out only for those that were directly provided by tourist enterprises. Statistical surveys and the determination of the volume of tourism services "are carried out in order to identify how tourism affects a nation's economy and balance of payments, as well as to identify the main trends of tourism development for planning its material and technical base, conducting market research and the promotion of products to potential consumers" (MILASHKO 2010). Characterizing tourism markets, V.H. Herasymenko \& V.Y. Pavlots'ky define the capacity of a regional market and propose a methodology for determining the quantitative indicators for the regional tourism services market (HERASYMENKO \& PAVLOTS'KYY 2011). Equally important are approaches to determining the quantity of tourist services provided and the calculation of the number of tourists within the Euroregion 'Upper Prut' (KYFYAK 2008).

It is known that at present, no country in the world systematically monitors tourism in full, and many countries, according to a report of the World Tourism Organization, have not provided any information on international tourism. Therefore, the issue of calculating the volume of travel services provided for tourists over a certain period of time and forecasting for future periods are relevant and important both for a particular region and for the country as a whole.

\section{PRESENTATION OF THE MAIN RESEARCH MATERIAL}

The calculation of the volume of tourist services and goods purchased by tourists in a certain territory, the forecast of demand for tourist services in the future and the definition of the place and role of tourism in the socio-economic development of a particular city or region, as well as the impact of tourism on the economic complex, is one of the tasks that the authorities put to academic organizations, tourist businesses and the public sector.

The definition of economic efficiency and social importance of tourism is considered in the accordance with baseline indicators, determined and calculated 
specially. In the State Classification of Types of Economic Activities in Ukraine, tourism is defined as a separate type of economic activity (section \#1 "Transport and Communications Activities", section 63.3, sub-section 63.30.0 "Services for organization of travel"), which includes tourism activity, intermediary activities of travel agents for the implementation of tourist product tour operators, the activity of guides (tourist), sale and reservation of tickets for any purpose (vacation, business trips, etc.) for travel by all modes of transport ${ }^{2}$. At the same time, the activities of sanatorium and resort establishments, hotels, restaurants, tourist centers, tourist transportation and other services are included in other sections of economic activities which greatly complicates the definition of the economic efficiency of the tourism industry in general.

Today the impact of tourism on the national economy, or of a region or city is unclear, the total volume consumed for a certain period of goods and services (as well as separately for each economic sector), it is impossible to allocate the proportion which is accounted for by tourist consumption, provided only through tourist activity and depends on the cash expenditure of tourists. It is practically impossible to allocate the share of goods or services purchased by tourists (for example, the amount of food consumed by tourists or communication services) from total sales, therefore the methodological problem of calculating the number of tourists visiting a certain territory and the volume of services provided for them requires a solution.

Using the example of the city of Chernivtsi, different approaches to calculating the volume of characteristic features and accompanying tourist services and purchased goods by tourists are offered. To calculate the volume of tourist services provided for tourists and the goods purchased within the city of Chernivtsi during 2017 as well as to determine their value, the following sources of information were used:

- data of Chernivtsi Regional State Tax Inspection;

- state statistical observation;

- administrative data;

- separate additional statistical studies;

- expert assessments.

According to a survey of 2370 tourists, the main list and the estimated cost of characteristic features of goods and services that were consumed by tourists during their stay were determined.

The calculation is based on the principle of taking into account Chernivtsi visitor spending, regardless of the motivation of the trip, as each visitor spent some money during the stay in the city, consuming goods and services of various sectors of the economy, which affects the entire economic and social sphere of the city.

The list of characteristic and uncharacteristic tourist services and goods consumed by tourists within the boundaries of Chernivtsi during 2017 (according to the State Classification of Products and Services of Ukraine) includes:

- hotel services with restaurants,

- catering services,

- beverage services with entertainment,

- transportation services,

- excursion buses,

- guided tours,

- services of tour operators and travel agents,

- services of leisure, entertainment, culture and sports,

- services of museums and other cultural-historical objects,

- financial and insurance services,

- other services (trade, information, consulting services, photographic services, translation, etc.).

According to the results of the survey, it was found that $22 \%$ of tourists visiting the city of Chernivtsi traveled independently, and the rest with friends, family or as part of tourist groups.

Taking as the basis the methodology for calculating the volume of tourism activity, approved by the joint order of the State Tourism Administration of Ukraine and the State Statistics Committee of Ukraine ${ }^{3}$ of November 12, 2003, \#142/394, as well as generalized information of a survey conducted based on tourists on the list, structure and cost of tourist services provided in 2017. It was established that foreign number of tourists and tourists from other regions of Ukraine who visited the city of Chernivtsi in 2017 spent an average of 1,645 UAH per day (amount per day - A/d) or 52 euros. While in Lviv, according to the tourism department of the Lviv City Council, on average, one tourist spent 2355 UAH or 75 euros per day ${ }^{4}$.

It is established that the average length of stay of one tourist in the city of Chernivtsi is 1.4 days (duration of stay $-\mathrm{d} / \mathrm{s}$ ). Thus, each tourist spent $2303 \mathrm{UAH}$ during the stay in the city.

According to the research, the daily expenses of tourists living in hotels in the city of Chernivtsi were as follows:

- the average cost of accommodation and meals was 928 UAH per day,

- services of tour operators and travel agents, transport expenses, excursions, entertainment programs - $541 \mathrm{UAH}$,

- purchase of souvenirs, accompanying goods and other expenses - $176 \mathrm{UAH}$.

According to the Chernivtsi Regional State Tax Inspectorate, in 2017 only tourist taxes from tourists staying in hotels in the city increased the budget of Chernivtsi by $258,200 \mathrm{UAH}$, which is by $71,400 \mathrm{UAH}$ or $27.6 \%$ more than the figures for the previous year ${ }^{5}$. And the total for accommodation services amounted to 25.8 million UAH, which indicates that 11,211 tourists stayed in hotels that pay a tourist tax. 
In general, according to the calculations on the basis of this methodology and the research conducted, the total amount for services rendered and goods purchased by tourists in the city in 2017 is about 720 million UAH. For comparison, in Lviv, according to the Lviv City Council Tourism Department, the total amount of consumed services and purchased goods (amount of services - A/s) by tourists in 2017 is almost 19 billion UAH, or 615 million euro ${ }^{6}$, which is 26.3 times more than in Chernivtsi.

The number of tourists $(Q t)$ that visited the city of Chernivtsi in 2017 according to the calculations is:

$$
\begin{gathered}
Q t=A / s:(A / d \times L / s)= \\
720000000 \text { UAH: (UAH } 1645 \times 1.4 \text { days })=312,635
\end{gathered}
$$

By comparison, Lviv, according to the tourist department of the Lviv City Council in 2017, was visited by 2.6 million tourists, with an average stay of 4.4 days ${ }^{7}$.

And, if we consider the tourist costs systematically, then we can see that the main expenditure goes on hotel, restaurant and tourist enterprises that provide services directly. Some of this comes from the payment of imports of goods and services consumed at the place of stay, and this does not continue to play a role in the economic activity of the city. The rest of the money is used to purchase local products and services, cover their own energy costs, pay, taxes, and more. In each every particular case, some amount of money accumulates, part is paid in the form of taxes and they cease to rotate in the economy of one or another territory.

The academic research undertaken also shows that 345 UAH per day, or $21 \%$ of the total daily expenditure, was spent by tourists in Chernivtsi for additional services, souvenirs, transport, and more.

The list of typical goods and services consumed by tourists during 2017 and their volume confirm that tourism directly or indirectly has a stimulating effect on the development of such types of economic activity as transport, hotels and restaurants, retail trade, food industry, construction, communications, insurance, financial intermediation, recreation and entertainment activities, culture and sports, etc. Tourism development stimulates the revival of the local economy and the creation of additional permanent and seasonal jobs. Tourist consumption actively supports the existence and development of souvenir production, folk crafts, national cultural heritage and others.

The annual analysis of the implementation of tourist services and goods in the city of Chernivtsi, carried out during the last five years (2012-16), and the establishment of many factors influencing tourist services, makes it possible to forecast the demand for travel services for the future period (3-5 years).

Thus, using statistical methods of forecasting demand for tourism services, which are the most widespread in the practice of forecasting the implementation of services, separate forecast indicators are calculated by different methods.

Statistical forecasting methods are based on trend models (extrapolation methods) and on factor models, which, in contrast to analogy methods and expert examination methods, show more realistic predictive data.

According to the Chernivtsi City Council, the volume of typical goods and services consumed by tourists in the city of Chernivtsi in 2012 amounted to 467.9 million $\mathrm{UAH}^{8}$, and in 2016 - UAH 657.5 million 9.

The average annual growth rate is calculated by the formula:

$$
\bar{K}=\sqrt[m-1]{\frac{y_{t}}{y_{1}}}
$$

where:

$\bar{K}$ - average annual growth rate,

$y_{t}-$ consumption of services in the reporting (last) year,

$y_{1}$ - realization of services in the base (first) year,

$m$ - number of years.

According to the calculations:

$$
\bar{K}=\sqrt[4]{\frac{657,5}{467,9}}=1,088
$$

the volume of sales of tourist services in the city of Chernivtsi, annually, over the last 5 years (2012-16), increased by an average of $8.8 \%(k)$.

Projection of the realization of services for the future:

2017 - 715.36 million UAH,

2018 - 778.31 million UAH,

2019 - 846.80 million UAH,

2020 - 921.31 million UAH.

It is extremely important that 2017 confirms the forecast indicators and the total volume of characteristic features of goods and services provided for tourists in the city of Chernivtsi in 2017 is about 720 million UAH.

Thus, after three years the consumption of typical goods and services by tourists will have increased to 921.31 million UAH and will reach a critical level of load on the general and tourist infrastructure and on the environment, which requires the development of appropriate infrastructure, additional attraction of material and labor resources, and maintaining the ecological balance.

\section{CONCLUSIONS}

Consequently, on the basis of the relevant calculations, the total volume of services provided and goods purchased, the number of tourists visiting the city, the 
average length of their stay and the expenditure of tourists during their stay are determined. On the basis of extrapolation average annual growth rate of characteristic and related services and forecasted their growth for future periods is calculated.

It is proved that tourism, directly or indirectly, through the consumption of various services, has a stimulating effect on the development of many types of economic activity.

The established list of services and goods and their quantity purchased by tourists, confirms that tourism through consumption directly or indirectly has a stimulating effect on the development of many spheres of economic activity and requires the development of an appropriate infrastructure, the additional attraction of material and labor resources and the maintenance of an ecological balance.

The prediction of tourism development is part of the forecast for the development of the economy and the social sphere of the city, which requires taking into account its features in contemporary conditions. In the future, the main directions of tourism development will be determined by social, economic, political and ecological factors. At the same time, processes of uncertainty and the existence of risk factors are getting more significant.

Academic research and the use of modern methods to calculate the volume of tourist services provided and goods purchased by tourists in the city of Chernivtsi, contributes to the real establishment of the number of tourists, as well as the determination of the influence of the tourism industry on the city economy and ways to solve many economic and social problems.

\section{ENDNOTES}

1 Naychastishe vidviduyut' Ukrayinu zhyteli Moldovy, Bilorusi ta Rosiyi [The most frequent visitors to Ukraine are residents of Moldova, Belarus and Russia] - infohrafika/ 29.01.2018. Retrieved from https://hromadske.ua/posts/naicha stishe-vidviduiut-ukrainu-zhyteli-moldovy-bilorusi-i-rosii-prykor donnyky [in Ukrainian].

2 KVED 2011, [State Classification of Types of Economic Activities in Ukraine]; http://howtoregister.com.ua/kved_2009. html.

${ }^{3}$ Pro zatverdzhennya Metodyky rozrakhunku obsyahiv turystychnoyi diyal'nosti: Nakaz Derzhavnoyi turystychnoyi administratsiyi Ukrayiny, Derzhavnoho komitetu statystyky Ukrayiny [On approval of the Methodology for calculating the volume of tourism activity: Order of the State Tourism Administration of Ukraine, State Statistics Committee of Ukraine] vid 12 lystopada 2003 r., 142/394; http://search. ligazakon.ua/1_ doc2.nsf/link1/REG8449.html [in Ukrainian].

${ }^{4}$ U 2017 rotsi turysty zalyshyly u L'vovi ponad pivmil'yarda yevro [n 2017, tourists left over half a billion euros in Lviv]; https://espreso.tv/news/2018/01/13/u_2017_roci_turysty_zalys hyly_u_lvovi_ponad_pivmilyarda_yevro [in Ukrainian].
5 Turystychnyy zbir popovnyv skarbnytsyu Chernivtsiv na mayzhe 260 tys. hrn. [The tourist collection replenished the Chernivtsi treasury by almost 260 thousand UAH]; /https:/ / pogliad.ua/news/money/turistichniy-zbir-popovniv-skarb nicyu-chernivciv-na-mayzhe-260-tis-grn-349005 [in Ukrainian].

${ }^{6}$ See $4^{\text {th }}$ endnote.

${ }^{7}$ See $4^{\text {th }}$ endnote.

8 Prohrama rozvytku turyzmu v misti Chernivtsyakh na 2013-2016 roky (2013). Rishennya Chernivets'koyi mis'koyi rady VI sklykannya 28.03.2013, 793. [Tourism development programs in the city of Chernivtsi for 2013-2016. Decision of the Chernivtsi City Council of the VI convocation of March 28, 2013, 793] Chernivtsi [in Ukrainian].

${ }^{9}$ See $4^{\text {th }}$ endnote.

\section{BIBLIOGRAPHY}

HerasymenKo V.H., PAVlOts'KyY V.Y., 2011, Metodyka vyznachennya kil'kisnykh pokaznykiv rehional'noho rynku turystychnykh posluh [Methodology for determining the quantitative indicators of the regional tourist services market], Rehional'na Ekonomika (Lviv), 2, pp. 157-163 [in Ukrainian].

KYFYAK V.F., 1995, Rozoytok mizhnarodnoho turyzmu yak odyn $z$ faktoriv stanovlennya ekonomiky Ukrayiny [Development of international tourism as one of the factors of the formation of the economy of Ukraine], "Ekonomika Ukrayiny", 7 (404) Kiev, «Presa Ukrayiny» [in Ukrainian].

KYFYAK V.F., 2008, Funktsionuvannya yevrorehionu «Verkhniy Prut» ta yoho rol' $v$ intehratsiynykh protsesakh Ukrayiny [Functioning of Euroregion 'Upper Prut' and its role in the integration processes of Ukraine], "Ekonomika Ukrayiny", 6 (559), Kiev, «Presa Ukrayiny» [in Ukrainian].

LISZEWSKI S., 2017, Miasto i turystyka. Wybór prac, Instytut Geografii Miast i Turyzmu Uniwersytetu Łódzkiego, Łódź.

MYLASHKO O.H., 2010, Statystyka turyzmu: Navchal'nyy posibnyk [Tourism mtatistics: textbook], Odesa, ODEU [in Ukrainian].

RAKADZHIESKA S., MARINOV S., 2005, Turisticheski pazari [Tourist markets], Izdatelska kusha STENO, Varna, 190 pp. [in Bolgarian].

SOBRAL F., PECI A., SOUZA G., 2007, An analysis of the dynamics of the tourism industry in Brazil: challenges and recommendations, "International Journal of Contemporary Hospitality Management", 19 (6), pp. 507-512; http:/ / citeseerx.ist.psu.edu/view doc $/$ download?doi=10.1.1.513.9451\&rep=rep1\&type=pdf.

STASIAK A., ŚLEDZINSKA J., WŁODARCZYK B., 2014, Szlaki turystyczne. Od pomystu do realizacji, Wyd. PTTK „Kraj”, Warszawa-Łódź.

TSYBUKH V.I., 2004, Pochty bespoleznye pokazately [Almost useless indicators], Kompan'yon, 43, pp. 36-41.

Article rceived:

17 February 2018

Accepted:

4 May 2018 